\title{
Originals
}

\section{Lactic Acidosis in Biguanide-Treated Diabetics}

\author{
A Review of 330 Cases \\ D. Luft, R. M. Schmülling, and M. Eggstein \\ Eberhard-Karls-Universität, Medizinische Klinik, Abteilung Innere Medizin IV, Tübingen, FRG
}

\begin{abstract}
Summary. The paper presents an analysis of clinical symptoms, signs and laboratory data of 330 diabetic patients who developed lactic acidosis after having been treated with biguanides (phenformin, buformin, metformin). From the review of the literature an attempt is made to find special features that predisposed patients to develop lactic acidosis such as accompanying illnesses and additional medications, to describe the course of illness and also the factors that influenced the prognosis. Of the patients that developed lactic acidosis $50.3 \%$ died. These patients were older, they suffered more frequently from cardiovascular shock, their acidosis was more severe, the whole blood lactate concentration was higher, and the degree of renal insufficiency was more advanced. From our observations we conclude that the treatment of diabetes mellitus with biguanides should be reserved for specially selected patients.
\end{abstract}

Key words: Diabetes mellitus, phenformin, buformin, metformin, lactic acidosis, adverse drug effects

In 1918 Watanabe [1] first described the hypoglycaemic action of guanidine. In the 1920's diguanides (synthalin A and synthalin B) were introduced for the treatment of diabetes mellitus. A few years later these drugs came into disrepute because of hepatotoxic effects in animals. These observations and the introduction of insulin led to the withdrawal of these agents. It was not until 1953 that substituted biguanides with a hypoglycaemic action were synthesized and in 1956 these were first used in the treatment of diabetics [2-5]. Of the large number of biguanides only three are in common usage:
1. Phenformin (1-( $\beta$-phenethyl)-biguanide)

2. Buformin (1-butyl-biguanide)

3. Metformin (1,1-dimethyl-biguanide).

Walker and Linton [6] in 1959 described the clinical picture of severe metabolic acidosis without ketosis in biguanide-treated diabetics. The accumulation of lactic acid soon became recognized as the cause of the acidosis. This severe metabolic disturbance was initially only rarely described and there was uncertainty whether the biguanides were the causative drugs [7]. Recently more and more cases have been reported from the USA, Great Britain, the Scandinavian countries, France and Germany. The laboratory proof of a markedly elevated concentration of biguanides in plasma and of lactate in whole blood has been made possible by the development of sensitive and specific biochemical methods $[8-10]$. This now allows for a reliable correlation between the use of biguanides and the development of lactic acidosis [11].

After a thorough review of the available literature, an attempt has been made to find characteristic features of patients suffering from lactic acidosis. These features include their histories, accompanying illnesses, additional drugs that were taken, course of their illness, and factors influencing the prognosis.

The biochemical aspects of lactic acidosis and the action of biguanides will not be discussed. Several reports over the past years have dealt with this subject [12-18].

\section{Methods}

The literature was reviewed by means of the Index Medicus and by collecting references of other published cases. In the evaluation of the case reports the following criteria had to be fulfilled: 


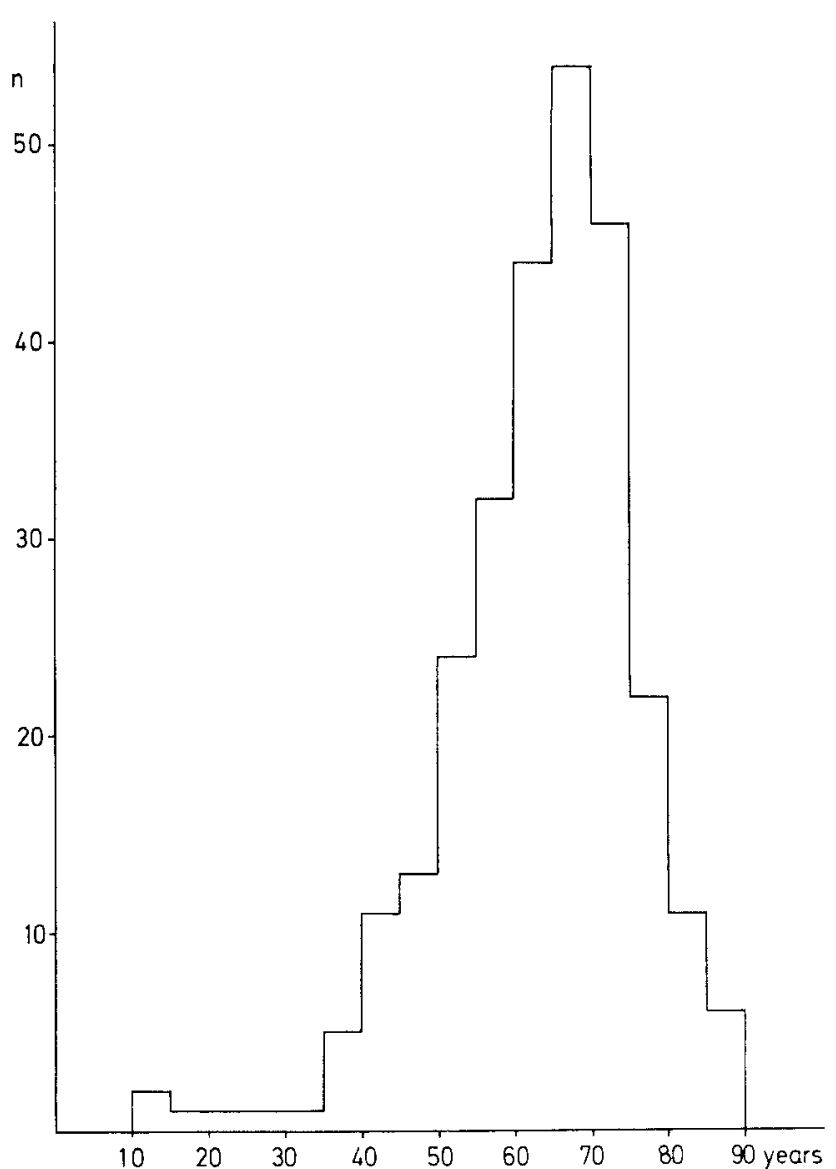

Fig. 1. Age distribution of 274 diabetic patients with lactic acidosis during biguanide treatment

1. The patient had to be a diabetic.

2 . The patient was taking biguanides before developing lactic acidosis.

3 . The patient had developed typical signs and symptoms suggestive of lactic acidosis.

4. A metabolic, non-ketotic acidosis and/or an elevated whole blood lactate was found.

A critical elevation of whole blood lactate or lowering of $\mathrm{pH}$ could not be used as a criterion because the state of lactic acidosis has so far not been biochemically clearly defined $[12,13,18-21]$.

References in which groups of patients with only mean values, standard deviations, or minimal and maximal recordings were described were excluded from our evaluation. Repeated case reports of the same patients were discarded while compiling the data; the references are, however, included in the index.

The data were collected in a 92-item-questionnaire, were then transferred to three punch-cards and evaluated in an IBM 1800 computer.

As statistical parameters we used the mean value and the standard error of the mean (SEM). Com- parisons of the mean values of the different groups were performed by using the two-tailed F-test. The difference of the mean values was regarded as significant at the 0.05 level.

The data bank is available for further evaluation.

\section{Results}

Between 1959 and 1977 at least 429 cases were reported which fit the criteria previously mentioned $[6,21-159]$.

In 99 cases the clinical, laboratory, and treatment data could not be associated with specific patients, so that these had to be excluded, leaving a total of 330. Nine reported cases of attempted suicide with biguanides were also excluded from the study $[25,35,40-42,48,57,62,66,68,90]$.

\section{Age and Sex Distribution}

The average age was 64 years $(n=274)$. The youngest patient was 13 years old, the oldest was 90 years old (Fig. 1). In 67 cases the sex was not reported. Of the remainder, $32.7 \%$ were males, and $67.3 \%$ were females. The male average age was 62 \pm 1 year ( $M \pm S E M, n=82$, range: $15-87$ years), the female average age was $65 \pm 1$ year $(n=167$, range: $13-90$ years).

A significant difference in the age distribution between males and females did not exist.

\section{Duration of Diabetes Mellitus before Development of Lactic Acidosis}

The duration of diabetes was reported in 174 patients. For 25 patients the diagnosis was established within 1 year before the development of lactic acidosis. Sixty-seven patients had suffered from diabetes for 1-6 years and 82 had diabetes for longer than 6 years.

\section{Treatment of Diabetes Mellitus}

\subsection{Treatment with Biguanides}

For only 3 of the 330 patients was the treatment not specified. Phenformin was used in 281 cases (1 patient had been treated with metformin previously and developed lactic acidosis 9 days after he was changed to phenformin). Buformin had been administered to 30 of the patients and metformin to 12 others. Another 4 patients had taken a combination of phenformin $(100-150 \mathrm{mg} / \mathrm{d})$ and metformin $(1000-1500 \mathrm{mg} / \mathrm{d})$. 
3.1.1. Dose of Phenformin: At the time the lactic acidosis developed the average phenformin dose was $123 \pm 4 \mathrm{mg} / \mathrm{d}(\mathrm{n}=213)$. The dosage was slightly higher in men $(128 \pm 7 \mathrm{mg} / \mathrm{d}, \mathrm{n}=63)$ than women $(117 \pm 4 \mathrm{mg} / \mathrm{d}, \mathrm{n}=135)$, but the difference is not statistically significant.

Only in 8 cases did the phenformin dose range between 200 and $300 \mathrm{mg} / \mathrm{d}$; one patient had received $400 \mathrm{mg} / \mathrm{d}$.

The diabetes had been treated with phenformin for 1 year in 81 cases, for 2 years in 23 cases, for 3 years in 16 cases, for 4 years in 4 cases, for 5 years in 3 cases and for longer than 5 years in 21 cases.

The doses for 48 patients had been increased or the treatment started with biguanides two weeks prior to the development of lactic acidosis. A sex difference in the duration of phenformin therapy was not demonstrable.

3.1.2. Dose of Buformin: For only 24 of 30 patients was a dose reported. In this group as in the previous one, the dose had occasionally increased before the development of the lactic acidosis. The "usual" therapeutic dose was $258 \pm 25 \mathrm{mg} / \mathrm{d}(\mathrm{n}=24)$, and the "actual" dose at the time of the lactic acidosis was $329 \pm 30 \mathrm{mg} / \mathrm{d}(\mathrm{n}=24)$.

3.1.3. Dose of Metformin: Dosages were reported in 10 of 12 patients. They ranged between 500 and $2400 \mathrm{mg} / \mathrm{d}(1595 \pm 182 \mathrm{mg} / \mathrm{d}, \mathrm{n}=10)$.

\subsection{Additional Treatment of the Diabetes Mellitus}

A combination of drugs was reported in 119 cases - 32 men, 76 women. The sex of 11 patients was not given. Combinations with sulfonylurea drugs were most frequently used (33 times with tolbutamide, 26 times with glibenclamide, 40 times with other sulfonylurea compounds). Nineteen patients received insulin concomitantly; one patient received insulin and tolbutamide.

\section{Accompanying Illnesses}

\subsection{Frequency}

At the time of treatment with biguanides 214 patients were reported to have other illnesses. Most frequently the patients had cardiovascular disease (n $=135)$, renal disease $(n=98)$, infectious processes $(n=45)$, hepatic disease $(n=39)$, and pulmonary disease $(n=16)$. See Table 1 .

\subsection{Treatment of the Accompanying Diseases}

4.2.1. Antibiotics: At least 14 patients received antibiotics before lactic acidosis became apparent.
Table 1. Frequency of accompanying illnesses

\begin{tabular}{llll}
\hline & & \multicolumn{2}{l}{ Survivors Deaths } \\
\cline { 3 - 4 } & & No autopsy & With autopsy \\
& $\mathrm{n}=143$ & $\mathrm{n}=65$ & $\mathrm{n}=80$ \\
\hline Cardiovascular disease & $44 \%$ & $43 \%$ & $64 \%$ \\
Renal disease & $35 \%$ & $31 \%$ & $51 \%$ \\
Infectious processes & $25 \%$ & $9 \%$ & $28 \%$ \\
Pulmonary disease & $19 \%$ & $11 \%$ & $35 \%$ \\
Hepatic disease & $15 \%$ & $9 \%$ & $28 \%$ \\
Shock & $24 \%$ & \multicolumn{2}{c}{$60 \%$} \\
Anuria & $17 \%$ & \multicolumn{2}{c}{$22 \%$} \\
\hline
\end{tabular}

Table 2. Complaints before establishing the diagnosis of lactic acidosis $(n=195)$

\begin{tabular}{lr}
\hline Symptoms & Number of patients \\
\hline Vomiting & 100 \\
Somnolence & 98 \\
Nausea & 71 \\
Epigastric pain & 69 \\
Loss of appetite & 52 \\
Hyperpnoea & 50 \\
Lethargy & 29 \\
Diarrhoea & 27 \\
Thirst & 8 \\
\hline
\end{tabular}

Drugs used were tetracyclines $(\mathrm{n}=5)$, gentamycin $(n=4)$, ampicillin $(n=3)$, cephalothin $(n=2)$, chloramphenicol $(\mathrm{n}=2)$, and rifampicin, ethambutol, cycloserine, thiamphenicol, penicillin, nalidixic acid, trimethoprim/sulfamethoxazole (once each).

4.2.2. Digitalis: At least 20 patients were digitalised. Digoxin derivatives were used predominantly.

4.2.3. Diuretics: Diuretics were used on 32 patients, most frequently thiazide-derivatives $(\mathrm{n}=14)$, furosemide $(n=14)$, spironolactone $(n=6)$, carbonic anhydrase inhibitor and mercurial diuretics $(\mathrm{n}=1)$.

4.2.4. Other Drugs: In addition to the above mentioned drugs the patients were also receiving the following: antihypertensive agents $(\mathrm{n}=18)$, barbiturates $(\mathrm{n}=4)$, steroids $(\mathrm{n}=2)$, and allopurinol $(\mathrm{n}$ $=1$ ). This allows one to infer the existence of associated diseases.

\subsection{Alcohol}

In 17 cases the patients were alcoholics or had taken large amounts of alcohol before lactic acidosis developed. 


\section{Symptoms at the Onset of Lactic Acidosis}

The symptoms in 195 patients before the diagnosis of lactic acidosis was made are listed in Table 2.

\section{Clinical Findings at the Time of Diagnosis}

\subsection{State of Consciousness}

A disturbed state of consciousness was reported for 177 of 212 patients. According to the descriptions of the various case reports we have tried to further subdivide the degree of unconsciousness (1: normal, 2: somnolence, 3: coma with reaction to external stimuli, 4: coma without reaction to external stimuli). It appeared that the state of somnolence predominated. In group 4 the blood glucose concentration was lowest $(124 \mathrm{mg} / 100 \mathrm{ml})$ and the serum urea concentration was highest $(146 \mathrm{mg} / 100 \mathrm{ml})$. The differences from group 1 (mean concentrations $195 \mathrm{mg} / 100 \mathrm{ml}$ and $103 \mathrm{mg} / 100 \mathrm{ml}$ respectively) are statistically significant $(2 \mathrm{p}<0.05)$. Significant differences for whole blood lactate concentration and osmolality could not be ascertained between the different groups.

\subsection{State of the Peripheral Circulation}

Skin colour and skin turgor were rarely mentioned. The following clinical findings were described: Dehydration was apparent in 62 cases, skin pallor in 62 cases, cyanosis in 27 cases. Often a combination of these signs existed. The most common finding was a combination of "pallor" and "dehydration".

\subsection{Evidence of Ketosis in the Expired Air}

This clinical observation typically found in diabetic ketoacidosis was only described eight times.

\subsection{Type of Respiration}

The respiratory rate varied correspondingly with the severity of the metabolic acidosis; a respiratory rate of over $20 / \mathrm{min}$ was found in 94 cases. A Kussmaultype respiration was described in 70 cases. The respiratory rate was normal in 13 patients; one patient had a respiratory rate below $12 / \mathrm{min}$.

\subsection{Cardiovascular State}

The present data suggest that the majority of the patients at the time of diagnosis manifested no symptoms of cardiovascular shock, and therefore no diminished supply of oxygen to peripheral tissues.
Only in 13 patients was cardiovascular shock described as the probable first sign of a severe attack of lactic acidosis. Signs of shock appeared later or during the course of treatment in 117 patients suffering from other symptoms of lactic acidosis. This classification is unreliable because the appearance of symptoms and clinical findings was only rarely listed in chronological fashion.

The average value for the pulse rate was 93 $\pm 2 / \min (n=106)$. A tachycardia of over $100 / \mathrm{min}$ was reported for 33 patients. In 5 cases the heart rate was described as "normal"; in 5 others it was "increased". The average systolic blood pressure (SBP) was $120 \pm 3 \mathrm{mmHg}(\mathrm{n}=183)$. In 72 cases the SBP at the time of diagnosis was below $100 \mathrm{mmHg}, 12$ patients had a "normal" SBP, and 20 patients had a "low" SBP. The average diastolic blood pressure was $72 \pm 2 \mathrm{mmHg}(\mathrm{n}=166)$.

\subsection{Body Temperature}

In 89 cases the average body temperature was 35.6 \pm 0.2 degrees $C$. The lowest recorded temperature was $26.7^{\circ} \mathrm{C}$. Eight other patients had a "lowered" body temperature, 13 were "normothermic", and 2 patients had an "elevated" body temperature.

\subsection{Urine Output at the Time of Diagnosis}

Of 76 patients 29 had a normal urine production (over $40 \mathrm{ml} /$ hour), but 47 patients had urine flow of less than $40 \mathrm{ml} /$ hour. Ten patients were described as being anuric, and a further 59 patients developed anuria during the course of treatment.

\subsection{Central Venous Pressure (CVP)}

A lowered CVP (less than $4 \mathrm{~cm} \mathrm{H}_{2} \mathrm{O}$ ) existed in 20 cases, a normal CVP $\left(4-10 \mathrm{~cm} \mathrm{H}_{2} \mathrm{O}\right)$ in 43 cases. A CVP of more than $10 \mathrm{~cm} \mathrm{H}_{2} \mathrm{O}$ was recorded in 21 cases.

\subsection{Myocardial Infarction}

In 4 cases myocardial infarction was diagnosed simultaneously with lactic acidosis. During treatment an additional 13 patients suffered a myocardial infarction.

\section{Biochemical Findings at the Time of Diagnosis}

In the present investigation only laboratory findings are evaluated which have significance for the clinical routine diagnosis (Table 3 ).

The laboratory examination indicated a decom- 
Table 3. Laboratory findings at the time of diagnosis of lactic acidosis and their prognostic significance. Anion gap: $\mathrm{Na}^{+}+\mathrm{K}^{+}-\mathrm{HCO}_{3}^{-}-\mathrm{Cl}^{-}$

Osmolality: $2 \times\left(\mathrm{Na}^{+}+\mathrm{K}^{+}\right)+\frac{\text { blood sugar }(\mathrm{mg} / \mathrm{dl})}{18}+\frac{\text { serum urea }(\mathrm{mg} / \mathrm{dl})}{6}$

\begin{tabular}{|c|c|c|c|c|c|c|c|c|c|c|c|}
\hline & & \multicolumn{3}{|c|}{ All patients } & \multicolumn{3}{|c|}{ Survivors } & \multicolumn{3}{|l|}{ Deaths } & \multirow[t]{2}{*}{$2 p$} \\
\hline & & Mean & SEM & $\mathrm{n}$ & $\overline{\text { Mean }}$ & SEM & $\mathrm{n}$ & $\overline{\text { Mean }}$ & SEM & $n$ & \\
\hline $\mathrm{pH}$ & & 6.95 & 0.11 & 278 & 7.00 & 0.12 & 122 & 6.91 & 0.17 & 118 & $<0.001$ \\
\hline $\mathrm{pCO}_{2}$ & $\mathrm{mmHg}$ & 21 & 1 & 152 & 22 & 1 & 78 & 19 & 1 & 64 & n.s. ${ }^{a}$ \\
\hline Bicarbonate & $\mathrm{mmol} / 1$ & 6.7 & 0.2 & 233 & 7.5 & 0.4 & 117 & 5.8 & 0.3 & 95 & $<0.001$ \\
\hline $\mathrm{pO}_{2}$ & $\mathrm{mmHg}$ & 106 & 4 & 63 & 105 & 7 & 20 & 104 & 5 & 31 & n.s. \\
\hline Lactate & $\mathrm{mmol} / 1$ & 16.9 & 0.5 & 268 & 15.6 & 0.8 & 116 & 18.5 & 0.8 & 114 & $<0.02$ \\
\hline Pyruvate & $\mathrm{mmol} / \mathrm{l}$ & 0.4 & 0.05 & 74 & 0.4 & 0.08 & 31 & 0.5 & 0.08 & 32 & n.s. \\
\hline L/P-ratio & & 71 & 10 & 73 & 81 & 19 & 30 & 60 & 11 & 32 & n.s. \\
\hline Anion gap & $\mathrm{mmol} / 1$ & 37 & 1.0 & 143 & 36 & 1.3 & 67 & 37 & 1.9 & 60 & n.s. \\
\hline Creatinine & $\mathrm{mg} / 100 \mathrm{ml}$ & 3.3 & 0.2 & 113 & 3.3 & 0.3 & 58 & 3.4 & 0.3 & 40 & n.s. \\
\hline Serum urea & $\mathrm{mg} / 100 \mathrm{ml}$ & 118 & 4.0 & 191 & 101 & 6.5 & 71 & 129 & 5.5 & 94 & $<0.005$ \\
\hline $\mathrm{Na}^{+}$ & $\mathrm{mmol} / 1$ & 138 & 0.6 & 145 & 138 & 0.8 & 73 & 138 & 0.9 & 55 & n.s. \\
\hline $\mathbf{K}^{+}$ & $\mathrm{mmol} / \mathrm{l}$ & 5.5 & 0.1 & 167 & 5.5 & 0.1 & 79 & 5.5 & 0.1 & 63 & n.s. \\
\hline $\mathrm{Cl}^{-}$ & $\mathrm{mmol} / \mathrm{l}$ & 97 & 0.8 & 125 & 98 & 1.1 & 61 & 95 & 1.2 & 47 & n.s. \\
\hline Phosphorus & $\mathrm{mmol} / \mathrm{l}$ & 1.9 & 0.2 & 17 & 1.7 & 0.3 & 8 & 2.2 & 0.2 & 9 & n.s. \\
\hline Blood sugar & $\mathrm{mg} / 100 \mathrm{ml}$ & 173 & 8.7 & 249 & 173 & 13.3 & 114 & 175 & 13.1 & 108 & n.s. \\
\hline Osmolality & $\mathrm{mosmol} / 1$ & 318 & 1.5 & 118 & 314 & 2.1 & 51 & 322 & 2.2 & 53 & $<0.02$ \\
\hline
\end{tabular}

a n.s.: not significant, $2 \mathrm{p}>0.05$

pensated metabolic acidosis with a marked ventilatory response (Fig. 2). The oxygen pressure was elevated due to marked hyperventilation. Of all patients, $81 \%$ had $\mathrm{pO}_{2}$-values above $80 \mathrm{mmHg}$, indicating that the oxygen supply to peripheral tissues was not diminished due to cardiovascular or pulmonary insufficiency. The lactate concentration in whole blood was elevated to $16.9 \mathrm{mmol} / \mathrm{l}$, with a raised lactate-pyruvate ratio fluctuating over a wide range. Serum urea and creatinine concentrations were elevated at the time of diagnosis. Unfortunately, little information is available about renal function before the onset of lactic acidosis. At least eight phenformin-treated patients had a normal serum creatinine concentration (less than $1.2 \mathrm{mg} / 100 \mathrm{ml}$ ) at the time of diagnosis.

The glucose concentration of the blood was not systematically changed; in most cases it is slightly elevated, but $26 \%$ of the patients with known blood sugar concentrations had values below $80 \mathrm{mg} / 100 \mathrm{ml}$ (Fig. 3).

The osmolality was moderately increased due to the elevation of glucose and urea.

The separation of groups according to pretreatment with different biguanides revealed little. Metformin pretreated patients appear to show minor metabolic disturbances although only the difference in the lactate concentration in whole blood between phenformin- and metformin-pretreated patients is statistically significant $(2 p<0.02)$. Though the dif-
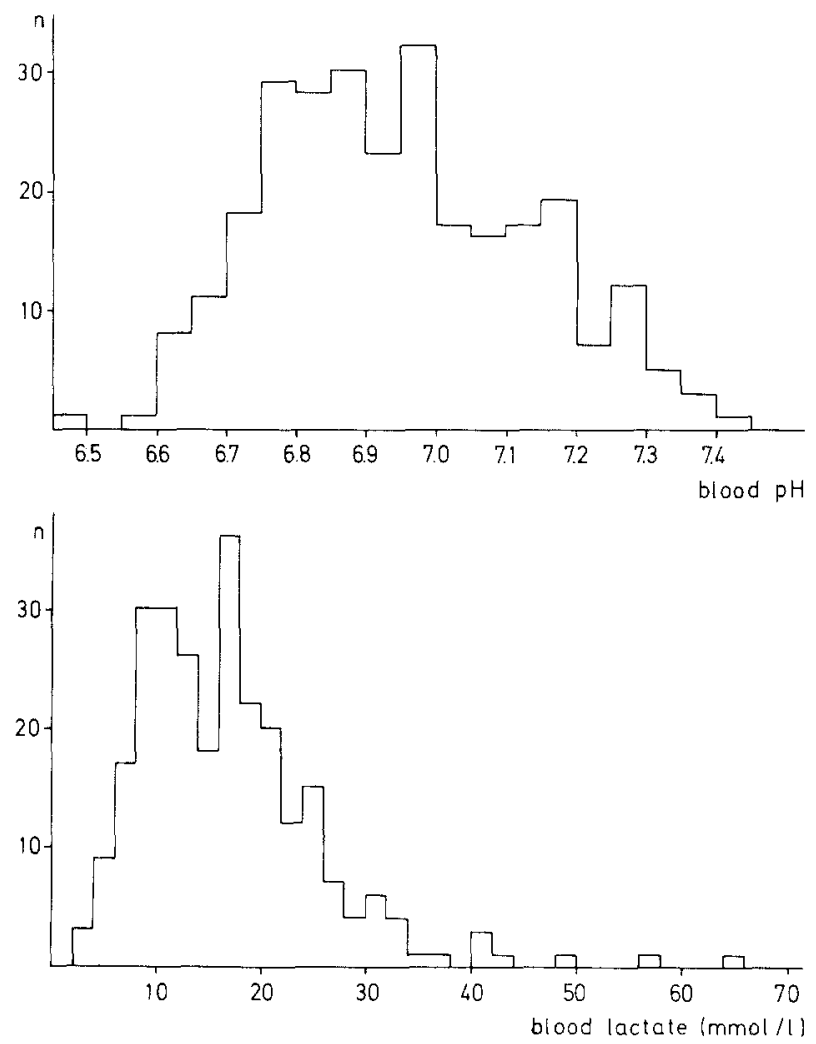

Fig. 2. Distribution of $\mathrm{pH}$ values $(\mathrm{n}=278)$ and of the lactate concentration in whole blood $(n=268)$ at the time of diagnosis of lactic acidosis during treatment of diabetes mellitus with biguanides 


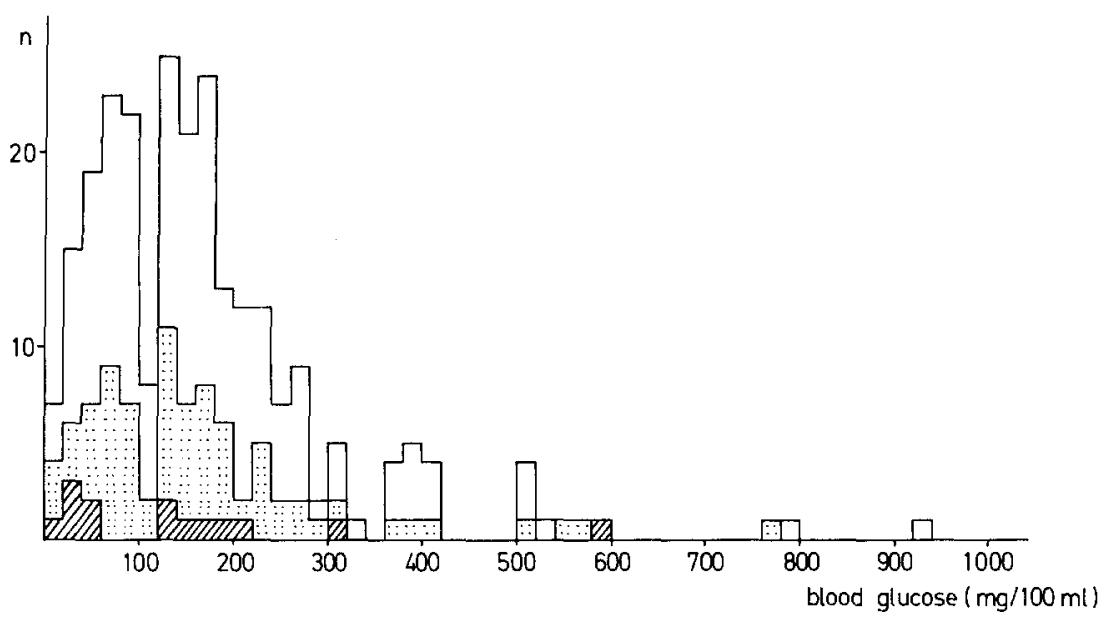

Fig. 3. Distribution of the concentration of glucose in the blood at the time of diagnosis of lactic acidosis. Hatched area: therapy with biguanides and insulin. Dotted area: therapy with biguanides and sulfonylurea compounds. Blank area: therapy with biguanides only

Table 4. Laboratory findings at the time of diagnosis of lactic acidosis due to different biguanide compounds. Mortality rate: number of dead patients and of all patients in brackets

\begin{tabular}{|c|c|c|c|c|c|c|c|c|c|c|}
\hline & & \multicolumn{3}{|c|}{ Phenformin-therapy } & \multicolumn{3}{|c|}{ Buformin-therapy } & \multicolumn{3}{|c|}{ Metformin-therapy } \\
\hline & & Mean & SEM & $\mathrm{n}$ & Mean & SEM & $\mathrm{n}$ & Mean & SEM & $\mathrm{n}$ \\
\hline $\mathrm{pH}$ & & 6.95 & 0.12 & 241 & 6.98 & 0.35 & 26 & 7.10 & 0.58 & 6 \\
\hline Bicarbonate & $\mathrm{mmol} / \mathrm{l}$ & 6.6 & 0.3 & 205 & 7.5 & 1.1 & 13 & 7.8 & 0.7 & 12 \\
\hline Lactate & $\mathrm{mmol} / 1$ & $17.3^{\mathrm{a}}$ & 0.6 & 227 & 16.1 & 1.6 & 25 & $12.8^{\mathrm{a}}$ & 1.4 & 11 \\
\hline Anion gap & $\mathrm{mmol} / \mathrm{l}$ & 37.4 & 1.1 & 131 & 45.1 & 8.8 & 3 & 34.3 & 5.7 & 5 \\
\hline Creatinine & $\mathrm{mg} / 100 \mathrm{ml}$ & $2.9^{\mathrm{b}}$ & 0.2 & 84 & $4.3^{\mathrm{b}}$ & 0.6 & 23 & 6.3 & 1.1 & 5 \\
\hline Serum urea & $\mathrm{mg} / 100 \mathrm{ml}$ & $114^{\mathrm{b}}$ & 4 & 172 & $160^{\mathrm{b}}$ & 20 & 12 & 111 & 29 & 3 \\
\hline Blood sugar & $\mathrm{mg} / 100 \mathrm{ml}$ & 176 & 9.6 & 213 & 150 & 24 & 22 & 172 & 50 & 11 \\
\hline Osmolality & $\operatorname{mosmol} / 1$ & $317^{\mathrm{b}}$ & 1.6 & 109 & $331^{b}$ & 3.8 & 4 & 327 & 14 & 2 \\
\hline Mortality & & \multicolumn{3}{|c|}{$52 \%(128 / 246)$} & \multicolumn{3}{|c|}{$50 \%(13 / 26)$} & \multicolumn{3}{|c|}{$18 \%(2 / 11)$} \\
\hline
\end{tabular}

a $2 \mathrm{p}<0.02$;

b $2 \mathrm{p}<0.05$

ferences in the creatinine and serum urea concentrations and the osmolality are striking, only between the phenformin- and the buformin-pretreated patients were the differences significant $(2 \mathrm{p}<0.05)($ Table 4$)$.

\section{Course of the Illness}

The time elapsed between the onset of symptoms to the time of diagnosis and from this stage to complete recovery (normalization of the acid-basebalance) or death was very short.

In $46 \%$ of 150 patients the diagnosis of lactic acidosis was made within 24 hours of the onset of symptoms, and $73 \%$ were diagnosed within 72 hours. The diagnosis of the remaining $27 \%$ was scattered over a period of up to 60 days. However, this long period is questionable because in this group there may have been patients who suffered only minor gastrointestinal disturbances.

The duration of treatment for 132 of 208 patients $(=64 \%)$ was less than 24 hours; in $88 \%$ of the cases the outcome of the illness was decided in 72 hours.
The duration of the illness was therefore very short - in $64 \%$ of patients less than 96 hours. There is no sex difference in the duration of symptoms before diagnosis, the length of treatment or the total duration of the illness.

\section{Treatment of the Lactic Acidosis}

\subsection{General Treatment Measures}

For shock the following treatments were used: vasopressor drugs $(n=47)$, steroids $(n=45)$ and volume expanders such as dextran, gelatine preparations, plasma, albumin, and whole blood $(\mathrm{n}=28)$.

Ventilation had to be either assisted or controlled in 16 patients. A further 14 patients received furosemide to enhance their diuresis while $14 \mathrm{pa}$ tients were digitalised.

\subsection{Specific Treatment Measures}

Information about specific treatment measures is available in 236 of all reported cases. Dose of treatment or outcome of therapy are not mentioned in about one half of these case reports. 
Therapy consisted of three main approaches:

1. Alkalinisation. In nearly all patients (n $=216$ ) restoration of $\mathrm{pH}$ was attempted with sodium bicarbonate. The amount of sodium bicarbonate used corresponded to the decrease of $\mathrm{pH}$. The mean $\mathrm{pH}$ in patients receiving up to 400 mmoles during the first 24 hours was 7.02 , the mean $\mathrm{pH}$ in patients receiving more than 800 mmoles was 6.86 .

Other buffers, such as THAM $(\mathrm{n}=17)$ and sodium lactate $(\mathrm{n}=3)$ have been used only rarely, because the first one offers no advantage and the second one has been abandoned because of pathophysiological considerations.

2. Haemodialysis $(\mathrm{n}=39)$ and peritoneal dialysis $(n=34)$. These methods have been recommended with different media (bicarbonate, acetate, lactate) in order to control complications due to the necessary alkalinisation (sodium and volume overload), to restore normal acid-base-balance and to eliminate accumulated biguanide and lactate. Recently very good results have been published with haemodialysis [117].

3. Administration of insulin and glucose ( $n$ $=94$ ) has been suggested in order to activate the pyruvate dehydrogenase system. Probably the overall effect of insulin is only positive if considerable amounts of ketone bodies participate in the metabolic acidosis.

The demonstration of an average anion gap of $36 \mathrm{mmol} / \mathrm{l}$ in the survivors (Table 3 ), which is accounted for by lactic acidaemia of $15.6 \mathrm{mmol} / 1$, indicates the presence of considerable amounts of acid anions such as ketone bodies.

Methylene blue infusion $(\mathrm{n}=16)$ has not been used in recent years.

\section{Outcome of the Treatment}

In 42 cases no mention of the outcome was made. Of the remaining patients $49.7 \%$ survived $(54.4 \%$ of the males and $48.7 \%$ of the females). In 80 cases $(=27.8 \%)$ a post-mortem examination was performed, but the findings in 60 patients only were recorded (see Table 1 ). A further $22.5 \%$ died without a post-mortem examination being carried out.

\section{Discussion}

\section{Diagnosis of Lactic Acidosis}

Till now exact information about the incidence of lactic acidosis in biguanide treated diabetics is not available, because not all cases diagnosed have been published or reported to the national drug administrations, not all suspected cases have been con- firmed by evaluation of the lactate concentration in whole blood, and probably a large number were not even suspected. Lactic acidosis in diabetics on biguanide therapy is diagnosed only to some extent because:

a) the clinical picture consists of symptoms and signs both of severe metabolic acidosis (vomiting, abdominal pain, nausea, air hunger, heavy laboured breathing) and of accompanying illnesses. These may be considered as the cause of the whole clinical picture, but only rarely is the function of the organs impaired to such a degree (e.g. cardiac insufficiency, myocardial infarction with cardiogenic shock, acute pulmonary insufficiency, renal insufficiency) to explain the severe metabolic acidosis. Mean systolic blood pressure and heart rate demonstrate that shock does not generally exist. The oxygen pressure excludes a hypoxia of peripheral tissues due to circulatory or ventilatory failure. A chronic impairment of renal function as the cause of the severe metabolic acidosis is not plausible in the light of the moderate elevation of creatinine and serum urea. An acute renal failure takes only two to three days to reach creatinine concentrations of about $3 \mathrm{mg} / 100 \mathrm{ml}$. Pronounced metabolic acidosis is unusual after this short time.

b) the laboratory examinations are equivocal and point to other complications of diabetes mellitus. Among 64 of 249 patients the concentration of blood glucose was less than $80 \mathrm{mg} / 100 \mathrm{ml}$ at the time of diagnosis leading to the preliminary diagnosis of hypoglycaemia, especially in patients treated with a combination of biguanide and insulin or sulfonylurea compound. In 24 cases the blood sugar concentration was more than $350 \mathrm{mg} / 100 \mathrm{ml}$ and in 55 cases mostly moderate reactions for ketone bodies in plasma could be demonstrated. Ketone bodies in urine were found in 78 patients. The expired air of 8 patients smelled of acetone. Thus diabetic ketoacidosis may be erroneously diagnosed, which may delay or prevent the correct diagnosis of lactic acidosis. On the other hand it is not correct to diagnose lactic acidosis and to exclude diabetic ketoacidosis if there is no reaction or only a moderate reaction for ketone bodies with the nitroprusside reagent, since it reacts with acetone and acetoacetate only but not with 3-hydroxy-butyrate. Only the measurement of lactate in whole blood can finally elucidate the origin of the acidosis. The decision is important because the therapeutic regimens and the prognosis are quite different $[160,161]$.

\section{Treatment of Diabetes Mellitus}

Adult diabetics are involved predominantly, which is in accordance with the indications of biguanides for 
the treatment of diabetes mellitus. Half of the patients were over 62 years old. Women were more frequently involved than men. Similar proportions are described for the incidence of diabetes mellitus in adults [162] and for the incidence of diabetic ketoacidosis; so that lactic acidosis does not favour either sex [163-165].

The number of published cases does not correspond with the real number of patients with lactic acidosis induced by the different biguanides. Probably phenformin induced lactic acidosis is commoner than the literature indicates. With more than 300 reported cases of phenformin induced lactic acidosis there is now little cause to publish single observations. Studies in France and Switzerland suggest that phenformin is more likely to produce lactic acidosis than metformin. In France $76 \%$ of all biguanide treated diabetics receive metformin, the remaining $24 \%$ receive phenformin, but only $14 \%$ of the published cases of lactic acidosis happened during metformin therapy, the remainder occurring during phenformin therapy [166]. Similar results were obtained in Switzerland [167]: The average shares in the Swiss biguanide market are: buformin $63 \%$, metformin $23 \%$, and phenformin $8 \%$. The share in the reported cases of lactic acidosis $(n=31)$ are: buformin $84 \%$, metformin $3 \%$, and phenformin $13 \%$. Furthermore metformin induced lactic acidosis seems to occur only with marked renal impairment [25]. The lowest serum creatinine concentration observed in our collected metformin cases was $3.0 \mathrm{mg} / 100 \mathrm{ml}$, whereas during phenformin therapy lactic acidosis was observed with normal - or approximately normal - creatinine concentrations (Table 4).

Besides some cases described in connection with metformin treatment are unclear and must be considered questionable $[27,166,168]$.

Lactic acidosis occurred with all three drugs while being used in a normal therapeutic dose. During the first two weeks after starting therapy or increasing the dose the diabetic patient appears more prone to develop lactic acidosis. Of the reported cases, $15 \%$ occurred at this time. One possible explanation is that the patient is suffering from a concommitant illness which is requiring additional diabetes therapy, and because of this biguanide therapy is commenced or increased.

In approximately one third of the cases, biguanides were used in combination with sulfonylurea drugs or insulin, so that a link between these drugs and the occurrence of lactic acidosis can be discussed. Sulfonylurea compounds alone have so far only rarely been associated with clinically relevant lactic acidosis [169]. An elevation of the con- centration of lactate in the whole blood after insulin administration is well known [170, 171], but it does not reach the levels described here.

\section{Accompanying Illnesses}

The presence of accompanying illnesses was always pointed out, as these have often been thought to be responsible, at least in part, for the lactic acidosis. In almost two third of the described patients such additional diseases are mentioned, but this should not be a surprising finding in 64 years old diabetic patients (at least concerning cardiovascular and renal diseases). It is possible that there were many more patients with other complications that were either not diagnosed or not mentioned: in post mortem examinations on 21 of 32 patients renal disease was found which had not been diagnosed clinically. Similar proportions are found in the other diseases. However, it is not justified to assume that all patients had associated severe illnesses. Even the patients who initially had markedly elevated serum urea and creatinine concentrations cannot be regarded principally as having advanced chronic renal failure since at least 6 had serum concentrations of creatinine less than $1.8 \mathrm{mg} / 100 \mathrm{ml}$ after recovery from lactic acidosis [172]. In general biguanide induced lactic acidosis occurred only rarely in the presence of normal renal function and in the absence of other diseases. However, it may be caused by only mild renal dysfunction due to acute gastroenteritis or biguanide induced gastrointestinal disturbances.

In some cases the treatment of the accompanying illness was mentioned. The part additional drugs play in the development or aggravation of lactic acidosis is uncertain, though alcohol certainly favours the development of lactic acidosis [173].

\section{Treatment of Lactic Acidosis}

The treatment is obviously unsatisfactory because the mortality rate remains $50 \%$. To elucidate the relation between outcome and given dose of a particular treatment, it is necessary to have regard to the severity of the disease in the individual patient given that dose. The severity of lactic acidosis is characterized by the factors being of prognostic significance: $\mathrm{pH}$, bicarbonate, lactate, serum urea, osmolality, age, and systolic blood pressure. Till now it is impossible to compare the effectiveness of different therapeutic regimens (e.g. bicarbonate therapy alone vs. bicarbonate therapy and haemodialysis) because the number of patients in the different groups with identical therapy and sufficient clinical data is too few. 
It is surprising that the mortality rate in patients with sufficient treatment data is only about 23 to $35 \%$ according to different treatment measures, because the mortality rate of the whole group is $50 \%$. It is evident that cases successfully treated are published more frequently with detailed description. This is true for bicarbonate therapy as well as combined insulin-glucose-infusion and haemodialysis. Therefore published mortality rates of about $30 \%$ for a particular treatment do not unequivocally mean a real superiority. A summary of treatment data is given in Table 5 .

\section{Prognosis}

There appears to be no sex difference. The mortality rate rises with age (Table 6). Accompanying illnesses are slightly more frequent in patients who died; this can be due to the additional information gained by the post-mortem examination (Table 1). Patients who showed evidence of shock at the time of diagnosis of lactic acidosis or who developed signs of shock in the further course of illness are found significantly more frequently among the dead patients (Table 1). The mortality of patients with shock was $70 \%$. The systolic blood pressure at the time of diagnosis has prognostic significance too: it is significantly higher in survivors $(135 \pm 4 \mathrm{mmHg}$, $\mathrm{n}=86)$ than in dead patients $(112 \pm 5 \mathrm{mmHg}$, $\mathrm{n}=77$ ).

A difference in the phenformin dose in patients who recovered $(125 \pm 6 \mathrm{mg} / \mathrm{d}, \mathrm{n}=98)$ and those who died $(120 \pm 5 \mathrm{mg} / \mathrm{d}, \mathrm{n}=92)$ cannot be established.

Patients who died of lactic acidosis had a significantly more severe metabolic acidosis at the time of diagnosis than the survivors. Their lactate concentration in whole blood and their serum osmolality was significantly higher. There is also a statistically significant difference in the serum urea concentration, but not the serum creatinine concentration. Patients who died had more markedly elevated serum urea concentrations. Possibly the biguanide intoxication is more pronounced in patients whose renal function is, at least temporarily, more severely impaired. These patients have a poorer prognosis.

\section{Conclusions}

Biguanides are used for the treatment of adult overweight diabetic patients. A life-threatening metabolic disturbance resulting from its use - lactic acidosis - has been reported with increasing frequency. Because of the high mortality rate of this disturbance it should be examined whether new
Table 5. Dosage of treatment in the first 24 hours after diagnosis of lactic acidosis

\begin{tabular}{|c|c|c|c|c|c|c|c|}
\hline \multirow[b]{2}{*}{ Treatment } & \multicolumn{3}{|c|}{ Survivors } & \multicolumn{3}{|c|}{ Deaths } & \multirow[b]{2}{*}{$\mathrm{p}$} \\
\hline & $\begin{array}{l}\text { Mean } \\
\text { Dose }\end{array}$ & SEM & $n$ & $\begin{array}{l}\text { Mean } \\
\text { Dose }\end{array}$ & SEM & $\mathrm{n}$ & \\
\hline $\mathrm{NaHCO}_{3}(\mathrm{mmol})$ & 549 & 38 & 67 & 505 & 54 & 35 & n.s. ${ }^{a}$ \\
\hline Insulin (IU) & 72 & 18 & 27 & 58 & 6 & 10 & n.s. \\
\hline Glucose (g) & 128 & 17 & 22 & 104 & 20 & 12 & n.s. \\
\hline
\end{tabular}

a n. s.: not significant, $2 \mathrm{p}>0.05$

Table 6. The mortality of lactic acidosis in the varying age groups. Mean values are given with SEM

\begin{tabular}{llll}
\hline Age & Surviving patients & Fatal outcome & Mortality \\
\hline 0-20 years & 3 & 0 & $0 \%$ \\
2r-40 years & 6 & 2 & $25 \%$ \\
41-60 years & 43 & 29 & $40.3 \%$ \\
over 60 years & 74 & 90 & $54.9 \%$ \\
Mean age & $62 \pm 1(126)$ & $66 \pm 1(121)$ & $2 \mathrm{p}<0.01$ \\
$\quad$ males & $58 \pm 2(42)$ & $67 \pm 2(33)$ & $2 \mathrm{p}<0.005$ \\
$\quad$ females & $63 \pm 2(75)$ & $66 \pm 1(77)$ & $2 \mathrm{p}>0.05$ \\
\hline
\end{tabular}

guide lines regarding its use can be established, in order to prevent this adverse effect.

We suggest that in the following instances biguanides should not be used for the treatment of diabetes mellitus:

a. Patients over 60 years of age

b. In the presence of accompanying illness, such as

- cardiovascular disease (coronary heart disease, angina pectoris, myocardial infarction, cardiac failure),

- renal disease (pyelonephritis, diabetic renal disease, elevated serum urea in post-renal obstruction such as prostatic hypertrophy) or proliferative retinopathy, since this complication of diabetes mellitus is almost always associated with diabetic renal disease,

- hepatic disease (hepatitis, cirrhosis, fatty change) etc).

- infectious processes (gangrene, pneumonia,

c. In states which can by themselves result in an accumulation of lactate such as:

- shock of varying origin

- diabetic ketoacidosis

- operations

- pulmonary insufficiency

- alcoholism

- weight-reducing diets or fasting

Treatment with biguanides should be stopped immediately, if 
a. one of the above mentioned conditions exists, b. gastrointestinal disturbances are noted,

c. the endogenous creatinine clearance drops below normal, since phenformin in therapeutic dose has accumulated in diabetics with normal serum creatinine concentration and reduced endogenous creatinine clearance [174].

Should lactic acidosis still continue to develop in biguanide-treated diabetic patients despite adhering to these strict criteria then the indications for its use in diabetes therapy should be thoroughly reevaluated [175].

\section{References}

1. Watanabe, C.K.: Studies in the metabolic changes induced by administration of guanidine bases. I. Influence of injected guanidine hydrochloride upon blood sugar content. J. Biol. Chem. 33, 253-265 (1918)

2. Krall, L.P., Camerini-Davalos, R.: Early clinical evaluation of a new oral non-sulfonylurea hypoglycemic agent. Proc. Soc. Exp. Biol. Med. 95, 345-347 (1957)

3. Pomeranze, J., Fujiy, H., Mouratoff, G. T.: Clinical report of a new hypoglycemic agent. Proc. Soc. Exp. Biol. Med. 95, 193-194 (1957)

4. Ungar, G., Freedman, L., Shapiro, S. L.: Pharmacological studies of a new oral hypoglycemic drug. Proc. Soc. Exp. Biol. Med. 95, 190-192 (1957)

5. Williams, R.H., Typerghein, J.M., Hyde, P.M., Nielsen, R. L.: Studies related to the hypoglycemic action of phenethyldiguanide. Metabolism 6, 311-319 (1957)

6. Walker, R. S., Linton, A. L.: Phenethyldiguanide: A dangerous side-effect. Br. Med. J. 1959 II, 1005-1006

7. Sadow, H.S.: This question of lactic acidosis. Postgrad. Med. J. 45 (Suppl.), 30-35 (1969)

8. Catellier, C., Fraser, E., Ayotte-Ferron, L., Savoie, J.-Y.: Plasma phenformin levels following a standard therapeutic dose in diabetics. Diabetes 25, 357 (1976)

9. Hrstka, V., Schmidt, F.H.: Die radioimmunologische Bestimmung von Phenformin in biologischen Flüssigkeiten. Vortrag Nr.25. 11. Kongreß der Deutschen Diabetesgesellschaft, Braunlage 1976

10. Ötting, F., Berger, W., Thomas, T., Talke, H.: Elimination von Biguaniden bei eingeschränkter Nierenfunktion, Vortrag Nr.41. 11. Kongreß der Deutschen Diabetesgesellschaft, Braunlage 1976

11. Karch, F.E., Lasagna, L.: Evaluating adverse drug reactions. Adversè Drug Reaction Bull. 59, 204-207 (1976)

12. Oliva, P. B.: Lactic acidosis. Am. J. Med. 48, 208-225 (1970)

13. Woods, H.F.: Some aspects of lactic acidosis. Br. J. Hosp. Med. 11, 668-676 (1971)

14. Mascetti, R., Mascetti, P.: Sull'acidosi lattica da biguanidi. Minerva Med. 63, 3930-3938 (1972)

15. Hermann, L.S.: Biguanides and lactate metabolism: a review. Dan. Med. Bull. 20, 65-79 (1973)

16. Assan, R., Heuclin, C., Girard, J. R., Attali, J. R.: Acidose lactique induite par les biguanides. Nouv. Presse Med. 5, 247-249 (1976)

17. Cohen, R.D., Woods, H.F.: Clinical and biochemical aspects of lactic acidosis. Oxford, London, Edinburgh, Melbourne: Blackwell Scientific Publications 1976
18. Harken, A. H.: Lactic acidosis. Surg. Gynecol. Obstet. 142, 593-606 (1976)

19. Huckabee, W.E.: Abnormal resting blood lactate. I. The significance of hyperlactatemia in hospitalized patients. Am. J. Med. 30, 833-839 (1961)

20. Huckabee, W. E.: Abnormal resting blood lactate. II. Lactic acidosis. Am. J. Med, 30, 840-848 (1961)

21. Tranquada, R.E., Grant, W.J., Peterson, C.R.: Lactic acidosis. Arch. Intern. Med. 117, 192-202 (1966)

22. Alberti, K. G.M.M., Corbett, J., Hockaday, T.D.R., Williamson, D. H.: Lactic acidosis. Br. Med. J. 1971 I, 47-48

23. Alling, B., Steen, B.: Analyser av mjölksyra och acetättiksyra $\mathrm{i}$ artärblod vid mjölksyraacidos hos fenforminbehandlad diabetiker. Lakartidningen 67, 4914-4916 (1970)

24. Althoff, P.-H., Fassbinder, W., Neubauer, M., Koch, K.M., Schöffling, K.: Lactatazidose - Hämodialyse, Dialyse von Lactat und Biguaniden, Vortrag Nr.1. 10. Kongreß der Deutschen Diabetesgesellschaft, Ulm 1975

25. Assan, R., Heuclin, C., Ganeval, D., Bismuth, Ch., George, J., Girard, J.R.: Metformin-induced lactic acidosis in the presence of acute renal failure. Diabetologia 13, 211-217 (1977)

26. Assan, R., Heuclin, C., Girard, J.R., LeMaire, F., Attali, J.R.: Phenformin-induced lactic acidosis in diabetic patients. Diabetes 24, 791-800 (1975)

27. Assan, R., Souchal, B., Aubert, Ph., Tchobroutsky, G., Dérot, M.: Comas métaboliques non acido-cétosiques chez des diabétiques. Presse Med. 77, 787-789 (1969)

28. Auzépy, Ph., Masliah-Planchon, R., Baulon, A., Lemonnier, A., Deparis, M.: Acidose lactique. Importance prognostique du diagnostic précoce. Ann. Med. Interne (Paris) 122, 13-20 (1971)

29. Azerad, E., Lubetzky, J., Duprey, J., Friedler, D.: L'acidose lactique chez les diabétiques. A propos de sept observations. Presse Med. 77, 1705-1708 (1969)

30. Azerad, E., Lubetzky, L., Duprey, J., Friedler, D., Weiss, A. M.: Six cas d'acidose lactique chez les diabétiques. Le Diabète (Le Raincy) 16, 87-95 (1968)

31. Ball, J. E., Lupin, A. M., Mary, C.C., Elliot, W.: Complications of therapy with oral hypoglycemic agents. J. La. State Med. Soc. 116, 353-356 (1964)

32. Ball, S., Woods, H.F., Alberti, K. G. M.M.: Lacticacidosis, ketoacidosis, and hyperalaninaemia in a phenformin-treated diabetic patient. Br. Med. J. 1974 IV, 699-700

33. Bengtsson, K., Karlberg, B., Lindgren, S.: Lactic acidosis in phenformin-treated diabetics. Acta Med. Scand. 191, 203-208 (1972)

34. Berger, W., Göschke, H., Ohnhaus, E.: Problèmes d'actualité concernant le mécanisme d'action des biguanides. Journ. Annu. Diabetol. Hotel Dieu 16, 239-258 (1975)

35. Berger, W., Mehnert-Aner, S., Mülly, K., Heierli, Ch., Ritz, R.: Zehn Fälle von Lactatazidose unter Biguanidtherapie (Buformin und Phenformin). Schweiz. Med. Wochenschr. 106, 1830-1834 (1976)

36. Bernier, G.M., Miller, M., Springate, C. S.: Lactic acidosis and phenformin hydrochloride. JAMA 184, 43-46 (1963)

37. Bernier, G. M., Springate, C.S., Miller, M.: Lactic acidosis and phenethylbiguanide. 22nd Meeting Am. Diab. Assoc., Chicago 1962

38. Bertrand, C.M.: Les hyperlactatémies pathologiques au cours des traitements par la phenformine. Presse Med. 78, 13-14 (1970)

39. Bierbach, H., Busch, S.: Letale Laktacidose unter Biguanidtherapie. Bericht über drei Fälle. Inn. Med. 4, 217-221 (1977)

40. Bingle, J.P., Storey, G.W., Winter, J. M.: Fatal self-poisoning with phenformin. Br. Med. J. 1970 III, 752 
41. Bismuth, Ch., Gaultier, M., Conso, F., Heuclin, C., Assan, R.: Acidose lactique induite par l'ingestion excessive de metformine. Nouv. Presse Med. 5, 261-263 (1976)

42. Bismuth, C., Gaultier, M., Conso, F., Assan, R., Heuclin, C.: Acidose lactique induite par l'ingestion excessive de metformin. Eur. J. Toxicol. Environ. Hyg. 9, 55-57 (1976)

43. Bjordahl, R.: Lactic acidosis in association with phenformin therapy: Report of two cases. J. Am. Osteopath. Assoc. 75, 1061-1065 (1976)

44. Blumenthal, S. A., Streeten, D.H.P.: Lactic acidosis in diabetics: Evidence for a primary etiologic role of phenformin. Diabetes 24, 428 (1975)

45. Blumenthal, S.A., Streeten, D. H.P.: Phenformin-related lactic acidosis in a thirty-year-old man. Ann. Intern. Med. 84, 55-56 (1976)

46. Böttiger, L. E.: Mjölksyraacidos och biguanider - en översikt. Lakartidningen 70, 3463-3464 (1973)

47. Bourdais, A.: L'épuration extrarénale dans les acidoses lactiques des diabétiques traités par la phenformine. Nouv. Presse Med. 2, 1273-1276 (1973)

48. Bourdais, A., Legall, F., Mathieu, H., Joly, R.: Traitement par hémodialyse et alcalinisation des acidoses lactiques des diabétiques recevant des biguanides. Soc. Med. Chir. Hop. Form. Sanit. Armees 3, 287-296 (1971)

49. Brach, B.B., Blackard, W., Rothschild, H.: A review of deaths due to suspected lactic acidosis at a large metropoli$\tan$ hospital. South. Med. J. 68, 202-205 (1975)

50. Brubakk, O., Hopen, G.: Melkesyreacidose behandlet med glukose og insulin. Tidsskr. Nor. Laegeforen. 95, 1412 1413 (1975)

51. Bryant, S., Bartley, P. C.: Phenformin-induced lactic acidosis in diabetes mellitus. Med. J. Aust. 1972 I, 1041-1044

52. Buess, H.J., Mihatsch, M.J., Wunderlich, P., Berger, W.: Laktatazidose bei Diabetes mellitus. Schweiz. Rundschau Med. (Praxis) 65, 406-413 (1976)

53. Butt, H., Reitinger, J.: Lactatacidose und Biguanidtherapie. Med. Klin. 72, 708-711 (1977)

54. Christiansen, J., Öberg, T.: Två fall av misstänkt laktatacidos i samband med fenforminbehandlad diabetes mellitus. Lakartidningen 69, 5425-5427 (1972)

55. Clavadetscher, P., Bischof, P., Wegmann, T.: Lactat-Acidose nach Buformin-Medikation. Dtsch. Med. Wochenschr. 101, 238-241 (1976)

56. Cleaver, T., Carretta, R.: Lactic acidosis with phenformin therapy. Calif. Med. 117, 14-19 (1972)

57. Cohen, R.D., Ward, J.D., Brain, A.J.S., Murray, C.R., Savage, T. M., Iles, R. A.: The relation between phenformin therapy and lactic acidosis. Diabetologia 9, 43-46 (1973)

58. Conlay, L.A., Loewenstein, J. E.: Phenformin and lactic acidosis. JAMA 235, 1575-1578 (1976)

59. Conlay, L. A., Matin, S. B., Loewenstein, J. E.: Serum phenformin concentrations in patients with phenformin-associated lactic acidosis. Diabetes 25, 359 (1976)

60. Coodley, E., Derasse, J., Carver, J.: Phenformin and pancreatitis. Letter to the editor. Ann. Intern. Med. 78, 307 (1973)

61. Curtes, J.P., Morio, B., Feuillu, A., Cartier, F.: Un cas d'hyper-lactatémie avec acidose, chez un diabétique traité par la phenformine. Eur. J. Toxicol. Environ. Hyg. 5, 361-365 (1972)

62. Davidson, M. B., Bozarth, W.R., Challoner, D.R., Goodner, C.J.: Phenformin, hypoglycemia and lactic acidosis. N. Engl. J. Med. 285, 886-888 (1966)

63. Debry, G., Laurent, J.: Acidose lactique et diabète sucré. Helv. Med. Acta 35, 433-447 (1969/70)

64. Dembo, A.J., Marliss, E. B., Halperin, M. L.: The role of insulin deficiency in the pathogenesis of phenformin-associated lactic acidosis. Diabetes 23, 370 (1974)
65. Dembo, A.J., Marliss, E.B., Halperin, M. L.: Insulin therapy in phenformin-associated lactic acidosis. Diabetes 24, 28-35 (1975)

66. Dobson, H.L.: Attempted suicide with phenformin. Diabetes 14, 811-812 (1965)

67. Duwoos, H., Bertrand, C. M., Husson, A., Cramer, J., Tayot, J.: Hyperlactatémie réversible induite par la phenformine avec asthénic musculaire et signes cardio-respiratoires. Presse Med. 78, 23-26 (1970)

68. Edwards, J.C.W.: Phenformin and lactic acidosis. Br. Med. J. 1976 I, 584

69. Ewy, G. A., Pabico, R. C., Maher, J.F., Mintz, D. H.: Lactate acidosis associated with phenformin therapy and localized tissue hypoxia. Ann. Intern. Med. 59, 878-883 (1963)

70. Fulop. M., Hoberman, H. D.: Phenformin-associated metabolic acidosis. Diabetes 25, 292-296 (1976)

71. Fulop, M., Hoberman, H.D., Rascoff, J.H., Bonheim, N. A., Dreyer, N.P., Tannenbaum, H.: Lactic acidosis in diabetic patients. Arch. Intern. Med. 136, 987-990 (1976)

72. Futral, J., Anton, N.: Phenformin and lactic acidosis. Ariz. Med. 28, 290-291 (1971)

73. Gale, E. A.M., Tattersall, R. B.: Can phenformin-induced lactic acidosis be prevented? Br. Med. J. 1976 II, 972-975

74. Gmeiner, R., Hammerle, P.: Laktatazidose bei mit Phenformin behandeltem Diabetes mellitus mit tödlichem Ausgang. Wien. Klin. Wochenschr. 86, 400-402 (1974)

75. Goldberg, L. D., Alterman, S. L.: Concurrent hypoglycemia and lactic acidosis in a diabetic treated with chlorpropamide and phenformin. South. Med. J. 66, 190-192 (1973)

76. Gong, W.C., Kato, D.B.: Phenformin induced lactic acidosis: A case report and review of the literature. Drug Intel. Clin. Pharm. 9, 236-240 (1975)

77. Gottlieb, A., Duberstein, J., Geller, A.: Phenformin acidosis. N. Engl. J. Med. 267, 806-809 (1962)

78. Graeber, G.M., Marmor, B.M., Hendel, R.C., Gregg, R. O.: Pancreatitis and severe metabolic abnormalities due to phenformin therapy. Arch. Surg. 111, 1014-1016 (1976)

79. Grivaux, M., Soulié, J., Diallo, A., Cosson, G., Chicandard, J.-F.: L'acidose lactique en réanimation. Ann. Med. Interne (Paris) 122, 105-112 (1971)

80. Grunst, J., Dobbelstein, H., Brinkmann, W., Edel, H.: Laktatazidose nach Phenylaethylbiguanid (Phenformin). Munch. Med. Wochenschr. 114, 1942-1945 (1972)

81. Haas, T., Sailer, D., Flügel, H., Ruppin, H., Matzkies, F.: Laktat-Azidose nach 5tägiger Phenformin-Medikation. Fortschr. Med. 94, 2074-2078 (1976)

82. Hansen, A. P., Braaten, J. T.: Maelkesyreacidose. En omtale af fem fatalt forløbende tilfaelde. Ugeskr. Laeger. 130, 805-811 (1968)

83. Hayat, J.C.: Le traitement de l'acidose lactique chez le diabétique par la dialyse péritonéale à l'acétate de sodium. Nouv. Presse Med. 2, 246 (1973)

84. Hayat, J.C.: The treatment of lactic acidosis in the diabetic patient by peritoneal dialysis using sodium acetate. A report of two cases. Diabetologia 10, 485-487 (1974)

85. Høier-Madsen, K., Andersen, M.: Maelkesyreacidose ved fenforminbehandlet diabetes mellitus behandlet med peritonealdialyse uden bikarbonattilførsel. Ugeskr. Laeger. 134, 1280-1281 (1972)

86. Isaacs, P.: Alcohol and phenformin in diabetes. Br. Med. J. 1970 III, 773-774

87. Jensen, H. A.: Treatment of lactic acidosis with insulin and glucose. Dan. Med. Bull. 20, 16-17 (1973)

88. Jensen, H. A., Hammer, A.: Maelkesyreacidose hos diabetiker i fenforminbehandling Nord. Med. 85, 469-471 (1971)

89. Johnson, H. K., Waterhouse, C.: Lactic acidosis and phenformin. Arch. Intern. Med. 122, 367-370 (1968) 
90. Karam, J., Matin, S., Levin, S., Forsham, P.H.: Circulating phenformin levels: Implications as to phenformin's therapeutic action. Diabetes 23, 375 (1974)

91. Knatterud, G.L., Klimt, C.R., Osborne, R. K., Meinert, C. L., Martin, D. B., Hawkins, B. S.: A study of the effects of hyoglycemic agents on vascular complications in patients with adult-onset diabetes: V. Evaluation of phenformin therapy. Diabetes 24 (Suppl. 1), 65-184 (1975)

92. Kristensen, O., Andersen, H. H.: Fenformininduseret maelkesyreacidose behandlet med glukose og insulin. Ugeskr. Laeger. 136, 2458-2459 (1974)

93. Kristensen, O., Andersen, H.H., Jensen, J. B.: Glucose-insulin treatment of lactic acidosis in phenformin-treated diabetics. Acta Med. Scand. 197, 463-465 (1975)

94. Kunz, F., Dienstl, F., Hörtnagl, H., Holzknecht, F., Lederer, B.: Lactatacidose und akute Verbrauchskoagulopathie bei Phenforminmedikation. Dtsch. Med. Wochenschr. 100, 1288-1291 (1975)

95. Lacher, J., Lasagna, L.: Phenformin and lactic acidosis. Clin. Pharmacol. Ther. 7, 477-481 (1966)

96. Larcan, A., Lambert, H.: L'acidose lactique, A propos de 42 observations collectées dans un service de réanimation. Journ. Annu. Diabetol. Hotel Dieu 17, 99-133 (1976)

97. Lebacq, E. G., Tirzmalis, A.: Metformin and lactic acidosis. Lancet 1972 I, 314-315

98. Levithan, A. A.: Phenformin and pancreatitis. Ann. Intern. Med. 78, 306-307 (1973)

99. Lindgren, S.: Mjölksyraacidos vid behandling med fenformin. Lakartidningen 66, 3705-3714 (1969)

100. Luft, D., Müller, P.H.: Laktazidose bei biguanidbehandelten Diabetikern. Med. Welt 28 (NF), 378-383 (1977)

101. Luft, D., Müller, P.H., Eggstein, M.: unpublished observation

102. Ly, B.E., Gedde-Dahl, D.: Fenforminindusert metabolsk acidose. En kasuistik. Tidsskr. Nor. Laegeforen 89, 1724-1726 (1969)

103. MacGregor, G. A., Poole-Wilson, P. A., Jones, N. F.: Phenformin and metabolic acidosis. Lancet 1972 I, 69-71

104. Marliss, E. B., Aoki, T. T., Toews, C. J., Felig, P., Connon, J. J., Kyner, J., Huckabee, W.E., Cahill, G.F., jr.: Amino acid metabolism in lactic acidosis. Am. J. Med. 52, 474-481 (1972)

105. Marliss, E. B., Ohman, J.L., jr., Aoki, T.T., Kozak, G.P.: Altered redox state obscuring ketoacidosis in diabetic patients with lactic acidosis. N. Engl. J. Med. 283, 978-980 (1970)

106. Marowski, B.: Phenformin, Niereninsuffizienz und Lactatacidose. Ther. Ggw. 113, 1706-1726 (1974)

107. Masliah-Planchon, R., Auzépy, Ph., Deparis, M.: L'acidose lactique des diabétiques traités par la phenformine. Eur. J. Toxicol. Environ. Hyg. 5, 316-321 (1972)

108. Meignan, M., Lemaire, F., Rapin, M., Assan, R.: Choc cardiogénique avec hypothermie compliquant l'acidose lactique aiguë secondaire à la phenformine. Nouv. Presse Med. 4, 1136-1138 (1975)

109. Mengis, C. L.: Lactic acid acidemia and phenformin. Rocky Mt. Med. J. 61, 39-41 (1964)

110. Merceron, R.E., Raymond, J.-P., Andreassian, B., Klotz, H.P.: Guérison d'un coma par acidose lactique chez une diabétique traitée par la phenyl ethyl biguanide. Le Diabète (Le Raincy) 20, 182-183 (1972)

111. Mestman, J. H., Pocock, D.S., Kirchner, A.: Lactic acidosis with recovery in diabetes mellitus on phenformin therapy. Calif. Med. 111, 181-185 (1969)

112. Milisci, R. E., Decherd, J., McFadden, E. R., Strader, W. J., III, Nusynowitz, M. L.: Phenformin-induced lactic acidosis. Recovery with massive bicarbonate therapy and hemodialysis. Am. J. Med. Sci. 265, 447-453 (1973)
113. Miller, M.: Side effects of the biguanide therapy and the problem of lactic acidosis. In: K. Oberdisse, H. Daweke, G. Michael (Hrsg.): 2nd. Internat. Biguanide Symposium, Düsseldorf, 1967, p 147-151. Stuttgart: G. Thieme Verlag 1968

114. Mirouze, J., Mion, Ch., Jullien, Ch., Beraud, J.-J.: Acidose lactique chez les diabétiques traités par la phenformine. Le Diabète (Le Raincy) 20, 33-37 (1972)

115. Mirouze, J., Mion, Ch., Beraud, J.-J., Selam, J.-L.: Acidose lactique à l'occasion d'insuffisance rénale chez deux diabétiques traités par metformine. Nouv. Presse Med. 5, 1004-1007 (1976)

116. Muller, A. J.: Lactic acidosis and bone marrow suppression due to oral hypoglycemic agents. J. Am. Osteopath. Assoc. 71, 1093-1097 (1972)

117. Neubauer, M., Althoff, P.-H., Fassbinder, W., Koch, M., Schöffling, K.: Zur Effektivität der Behandlung der Biguanid-induzierten Lactat-Azidose durch Hämodialyse, Vortrag Nr. 45. 12. Kongreß der Deutschen Diabetesgesellschaft, Homburg/Saar 1977

118. Oliva, P. B.: Phenformin and lactic acidosis. Report of a case and review of the literature. Med. Ann. DC 38, 548-552 (1969)

119. Payne, J. R.: Clinically severe lactic acidosis with coma. Calif. Med. 105, 281-284 (1966)

120. Phillipson, E. A., Sproule, B. J.: The clinical significance of elevated blood lactate. Can. Med. Assoc. J. 92, 1334-1338 (1965)

121. Piñon-Selles, F., Gudin-Herrero, J.: Acidosis lactica de rapida evolucion en diabetico tratado con fenformina. Rev. Clin. Esp. 128, 535-538 (1973)

122. Proctor, D.W., Stowers, J.M.: Fatal lactic acidosis after an overdose of phenformin. Br. Med. J. 1967 IV, 216

123. Reitan, J. A., Stephens, R. B., Warpinski, M. A.: Phenformin-induced lactic acidosis and anesthesia. Anesthesiology 39, 562-564 (1973)

124. Riedler, G.F., Keusch, G., Schmid, M.: Knochenmarktoxizität, Laktatazidose und disseminierte intravasale Gerinnung nach Phenforminmedikation. Schweiz. Med. Wochenschr. 104, 1160-1166 (1974)

125. Robert, M., Truchet, P., Veyrat, A.: Acidose lactique chez une diabétique traitée par le $\mathrm{N}, \mathrm{N}$-dimethylbiguanide. Lyon Med. 229, 1143-1146 (1973)

126. Robin, E.D.: Dynamic aspects of metabolic acid base disturbances: Phenformin lactic acidosis with alkaline overshoot. Trans. Assoc. Am. Physicians 85, 317-324 (1972)

127. Romankiewicz, J. A.: Phenformin-associated lactic acidosis: a review. Am. J. Hosp. Pharm. 32, 502-507 (1975)

128. Salky, N., Hatch, F. E.: Lactic acidosis in diabetics treated with phenformin (DBI). J. Tenn. Med. Assoc. 61, 879-881 (1968)

129. Schaffalitzky de Muckadell, O. B., Køster, A., Jensen, S. L.: Fenformin-alkohol-interaktion: Maelkesyreacidose og hypoglykaemi hos patienter med stabil diabetes mellitus. Ugeskr. Laeger. 135, 925-927 (1973)

130. Selroos, O., Pasternack, A., Kuhlbäck, B.: Laktatacidos och fenformin. Ett fall framgangsrikt behandlat med hemodialys. Nord. Med. 80, 1658-1661 (1968)

131. Sheppard, J.M., Lawrence, J.R., Oon, R.C.S., Thomas, D.W., Row, P.G., Wise, P.H.: Lactic acidosis: Recovery associated with use of peritoneal dialysis. Aust. NZ. J. Med. 1972 IV , 389-392

132. Shirriffs, G.G., Bewsher, P.D.: Hypothermia, abdominal pain, and lactic acidosis in phenformin-treated diabetic. Br. Med. J. 1970 III, 506

133. Simpson, I. J., Henley, J.W., Sharpe, D. N.: Lactic acidosis associated with phenformin therapy in diabetes mellitus. NZ. Med. J. 79, 645-648 (1974) 
134. Sproule, B. J., Phillipson, E. A., Couves, C.M., Brownlee, R.T.: Acute pulmonary hypertension in idiopathic lactic acidosis. Can. Med. Assoc. J. 94, 141-143 (1966)

135. Strandgaard, S.: Svaer metabolisk acidose hos diabetiker $i$ behandling med fenformin og allopurinol. En følge af medikamentel interaktion? Ugeskr. Laeger. 132, 1834-1836 (1970)

136. Strauss, F. G., Sullivan, M. A.: Phenformin intoxication resulting in lactic acidosis. Johns Hopkins Med. J. 128, 278-281 (1971)

137. Strohmeyer, G., Dölle, W., Sauer, H.: Milchsäureacidose mit Excesslactat bei Diabetes mellitus. Dtsch. Med. Wochenschr. 90, 2238-2240 (1965)

138. Talke, H., Maier, K.P., Scholz, H., Jontofsohn, R.: Zur Therapie der biguanidinduzierten Laktatazidose. Verh. Dtsch. Ges. Inn. Med. 81, 704-705 (1975)

139. Talke, H., Scholz, H., Jontofsohn, R., Maier, K. P.: Laktatazidose während Phenformintherapie. Erfolgreiche Behandlung durch Hämodialyse und Bikarbonatinfusion. Therapiewoche 24, 6124-6127 (1974)

140. Talke, H., Scholz, H., Jontofsohn, R., Maier, K.P.: Laktatazidose während Phenformin-Therapie. Erfolgreiche Behandlung durch Hämodialyse und Bicarbonatinfusion. Inn. Med. 2, 80-85 (1974)

141. Tashima, C. K.: Phenformin, tetracycline, and lactic acidosis. Br. Med. J. 1971 IV, 557-558

142. Tashima, C. K.: Hypoglycemia and probable lactic acidosis during phenformin therapy. Hawaii Med. J. 32, 332-334 (1973)

143. Thimme, W., Buschmann, H.-J., Dissmann, W., Amft, R.: Biguanidtherapie und Lactatacidose. Med. Klin. 71, 1429-1433 (1976)

144. Tilling, W., Stein, G.: Lactatacidose. Dtsch. Med. Wochenschr. 95, 2336-2339 (1970)

145. Tomkins, A.M., Jones, R., Bloom, A.: Lactic acidosis occurring during phenformin therapy. Postgrad. Med. J. 48, 386-387 (1972)

146. Tranquada, R.E., Bernstein, S., Grant, W.J.: Intravenous methylene blue in the therapy of lactic acidosis. Arch. Intern. Med. 114, 13-25 (1964)

147. Tranquada, R. E., Bernstein, S., Martin, H.E.: Irreversible lactic acidosis associated with phenformin therapy. JAMA 184, 37-42 (1963)

148. Tugaye, A., Rendu, Ch., Deuil, R.: Coma avec acidose lactique chez une diabétique traitée par le phénéthylbiguanide. Cah. Coll. Med. Hop. Paris 9, 1055-1057 (1968)

149. Vinik, A. I., Jackson, W.P. U.: Lactic acidosis in diabetics. S. Afr. Med. J. 48, 2021-2026 (1974)

150. Walker, R. S.: Lactic acidosis through medicaments. Helv. Med. Acta 35, 448-455 (1969/70)

151. Walker, R.S., Hannah, R.: Experiences with phenformin (a two-year study). Diabetes 10, 275-279 (1961)

152. Wegner, B., Muche, J.: Laktatazidose unter BuforminTherapie. Dtsch. Gesundh.-Wesen 32, 1040-1044 (1977)

153. Westervelt, F. B., jr., Owen, J. A., jr., Hornbaker, J.H., jr., Gorsuch, T.L.: Lactic acidosis: a case treated with THAM and hemodialysis. Va. Med. Mon. 93, 251-256 (1966)

154. Westervelt, F.B., jr., Owen, J. A., jr., Hornbaker, J.H., jr., Rhodes, A. G.: Severe lactic acidosis successfully treated with THAM and hemodialysis. Clin. Res. Proc. 13, 55 (1965)

155. Williams, D. N., Knight, A.H., Goldberg, D. M.: Lactic acidosis and hyperamylasaemia associated with phenformin therapy. Postgrad. Med. J. 50, 765-766 (1974)

156. Williamson, M.: Lactic acidosis: Report of case and review of literature. J. Am. Osteopath. Assoc. 75, 803-819 (1976)
157. Wise, P.H., Chapman, M., Thomas, D. W., Clarkson, A. R., Harding, P.E., Edwards, J.B.: Phenformin and lactic acidosis. Br. Med. J. 1976 I, 70-72

158. Wittmann, P., Haslbeck, M., Bachmann, W., Mehnert, H.: Lactacidosen bei Diabetikern unter Biguanidbehandlung. Dtsch. Med. Wochenschr. 102, 5-10 (1977)

159. Young, J.M., Armanino, L. P.: Lactic acidosis and phenformin intoxication. Report of two cases with review of literature. Calif. Med. 103, 198-202 (1965)

160. Alberti, K.G.M.M., Nattrass, M.: Lactic acidosis. Lancet 1977 II, 25-29

161. Wittmann, P., Haslbeck, M., Bachmann, W., Mehnert, H.: Verlauf und Therapie bei Diabetikern mit Lactacidosen nach Biguanidbehandlung: Klinische Konsequenzen. Vortrag Nr.69. 12. Kongreß der Deutschen Diabetesgesellschaft, Homburg/Saar 1977

162. Panzram, G.: Epidemiologie des Coma diabeticum. Schweiz. Med. Wochenschr. 103, 203-208 (1973)

163. Beigelman, P.M.: Severe diabetic ketoacidosis (diabetic "coma"). 482 episodes in 257 patients: experience of three years. Diabetes 20, 490-500 (1971)

164. Keller, U., Berger, W., Ritz, R., Truog, P.: Course and prognosis of 86 episodes of diabetic coma. Diabetologia 11, 93-100 (1975)

165. Prachar, H., Bruneder, H., Nobis, H., Korp, W.: Coma diabeticum. Bericht über 752 Fälle (1931-1973). Munch. Med. Wochenschr. 117, 661-668 (1975)

166. Isnard, F., Lavieuville, M.: Acidose lactique et biguanides: Etat actuel de la question en France. Journ. Annu. Diabetol. Hotel Dieu 18, 362-375 (1977)

167. Berger, W.: Discussion remark. 12. Kongreß der Deutschen Diabetesgesellschaft, Homburg/Saar 1977

168. Harding, A.P.: Lactic acidosis and biguanides. NZ. Med. J. 80, 31 (1974)

169. Freeman, H., Campbell, D.: Therapy of lactic acidosis. N. Engl. J. Med. 292, 263-264 (1975)

170. Eggstein, M.: Zur Regulation des Serumneutralfettes und seiner Spaltprodukte und von Glukose, Laktat und Pyruvat im Blut. Verh. Dtsch. Ges. Inn. Med. 71, 476-479 (1965)

171. Eggstein, M., Knodel, W.: Kohlenhydrat - und Fettstoffwechselprodukte im Blut nach Insulin und Rastinon. Verh. Dtsch. Ges. Inn. Med. 72, 754-757 (1966)

172. Vinik, A.I., Jackson, W.P.U.: Lactic acidosis in diabetics. S. Afr. Med. J. 49, 301 (1975)

173. Kreisberg, R. A., Owen, W.C., Siegal, A.M.: Hyperlacticacidemia in man: ethanol-phenformin synergism. J. Clin. Endocrinol. Metab. 34, 29-35 (1972)

174. Spaethe, R., Hrstka, V., Schmidt, F. H., Otto, H.: Verlauf von Plasmalactat und Serum-Phenformin bei Diabetikern während einer kontrollierten Studie mit steigenden Phenformindosen, Vortrag Nr.62. 12. Kongreß der Deutschen Diabetesgesellschaft, Homburg/Saar 1977

175. Williams, R.H., Palmer, J.P.: Farewell to phenformin for treating diabetes mellitus. Ann. Intern. Med. 83, 567-568 (1975)

Received: May 5, 1977,

and in revised form: August 16, 1977

Dr. D. Luft

Medizinische Universitätsklinik

Abt. Innere Medizin IV

Otfried Müller-Straße 10

D-7400 Tübingen 1

Federal Republic of Germany 